\title{
Use of a plastic banded bag over the control body of the endoscope for COVID-19 prevention: a comment
}

I would like to share ideas and comment on the publication "Use of a plastic banded bag over the control body of the endoscope as a splash guard to minimize the biological hazard during the COVID19 outbreak" [1]. The prevention of COVID-19 is an important consideration in medicine; in clinical endoscopy, prevention is necessary. Using a plastic banded bag over the control body of the endoscope is a good idea for risk minimization of COVID-19. Nevertheless, it is questionable whether a plastic banded bag is effective for this purpose or not, because the SARS-CoV-2 virus is a small virus (about $1 \mu \mathrm{m}$ ). With the size of the virus being extremely small, it might be smaller than the pore size of the plastic bag. This is the same physical fact that means some kinds of facemask are not useful for coronavirus prevention [2, 3]. Because there are various kinds of plastic bag, which have different pore sizes, the selection of a plastic bag that has a very small pore size is necessary if it is to be used for endoscope coverage.
Competing interests

The author declares that he has no conflict of interest.

The author

\section{Viroj Wiwanitkit}

Department of Community Medicine, Dr DY

Patil University, Pune, India

\section{Corresponding author}

Viroj Wiwanitkit, MD

Department of Community Medicine, Dr DY Patil University, Pune, 411018 , India

wviroj@yahoo.com
References

[1] Bojórquez A, Súbtil JC, Betés MT et al. Use of a plastic banded bag over the control body of the endoscope as a splash guard to minimize the biological hazard during the COVID-19 outbreak. Endoscopy 2020; 52: 818

[2] Wiwanitkit V. MERS-CoV, surgical mask and N95 respirators. Singapore Med J 2014; 55 : 507

[3] Sriwijitalai W, Wiwanitkit V. N-95 face mask for prevention of Wuhan novel coronavirus: It is actually effective? Int J Prev Med 2020; 11: 81

\section{Bibliography}

Endoscopy 2020; 52: 1149

DOI 10.1055/a-1276-0364

ISSN 0013-726X

published online 30.10 .2020

(c) 2020. Thieme. All rights reserved.

Georg Thieme Verlag KG Rüdigerstraße 14,

70469 Stuttgart, Germany 